1. Smigaj W., Betcke T., Arridge S., Phillips J., Schweiger M. Solving boundary integral problems with BEM++. ACM Trans. Math. Softw. 2015, Vol. 41, No. 2, Article 6. doi: http://dx.doi.org/10.1145/2590830.

2. LeVeque R. J. Finite Volume Methods for Hyperbolic Problems. Cambridge University Press. 2002,P. 687. https://doi.org/10.1017/CBO9780511791253.

3. Tupholme G. E. Generation of acoustic pulses by baffled plane pistons. Mathematika. 1969 ,Vol. 16, P. $209-224$. doi:10.1112/S0025579300008184/

4. Stepanishen P. R. The time-dependent force and radiation impedance on a piston in a rigid infinite planar baffle. J. Acoust. Soc. Am, 1971 , Vol. 49, P. 841-849. doi: 10.1121/1.1912424.

5. Stepanishen P. R. Transient radiation from pistons in an infinite planar baffle. J. Acoust. Soc. Am. 1971, Vol. 49, P. 1629-1638. https://doi.org/10.1121/1.1912541.

6. Thierry B., Xavier A., Chokri C., Alzubaidi H. Mu-diff: an Open-Source Matlab Toolbox for Computing Multiple Scattering Problems by Disks. Computer Physics Communications. 2015, Vol.192, P. 348-362.

doi: 10.1016/j.cpc.2015.03.013.

7. http://www.simsonic.fr.

8. FOCUS Quick Start Guide. Michigan State University. November, 2013. https://www.egr.msu.edu/ fultrasweb/files/documentation/Field-to-FOCUS.pdf.

9. Lingvall F. User Manual for the DREAM Toolbox. 2009.

10. Lee Y.-S. Numerical solution of the KZK equation for pulsed finite amplitude sound beams in thermoviscous fluids. The University of Texas at Austin: Ph.D. dissertation, 1993.

11. Pozzi S., Borrazzov C., Carnì M., Di Castro E., Valentini S., Caccia B. A computational tool for evaluating HIFU safety. Ann Ist Super Sanità. 2016, Vol. 52, No. 2, P. 256-260. doi: 10.4415/ANN_16_02_18.

12. Treeby B. E., Cox B. T. k-Wave: MATLAB toolbox for the simulation and reconstruction of photoacoustic wave fields. Journal of Biomedical Optics. 2010, Vol. 15, No. 2. doi: 10.1117/1.3360308.

13. Morkun V. S., Morkun N. V., Pikilnyak A. V. Augmented reality as a tool for visualization of ultrasound propagation in heterogeneous media based on the k-space method. CEUR Workshop Proceedings. 2020, Vol. 2547, P. 81-91.

14. Morkun, V., Pikilnyak, A. Simulation of high-energy ultrasound propagation in heterogeneous medium using kspace method. Metallurgical and Mining Industry. 2014, Vol. 6, P. 23-27.

15. Morkun, V., Morkun, N., Pikilnyak, A. Iron ore flotation process control and optimization using high-energy ultrasound. Metallurgical and Mining Industry. 2014, Vol. 6(2), P. 36-42.

Рукопис подано до редакції 21.03.2020

UDC 331.101.38:622.012

N.G. KUTOVA ; Candidate of Economic Sciences, Senior Lecturer, A.Y. SHAKHNO, Doctor of Economic Sciences, Assoc. Prof., K.O. DEMIANENKO, student, Kryvyi Rih National University

\title{
DETERMINATION OF THE INFLUENCE OF FACTORS ON THE STATE OF PERSONNEL INCENTIVES OF THE INDUSTRIAL ENTERPRISES
}

Purpose. To conduct diagnostics of personnel incentives, by which it is necessary to establish the influence of certain factors on the productivity of personnel at enterprises.

Research methods. The methods of statistical analysis, regression analysis, modelling of economic indicators using MS Excel are used.

Scientific novelty lies in the identification of significant factors for the stimulation of personnel to form an evaluation system improving the economic mechanism of incentives for the personnel at enterprises.

Practical value is that the results of the study revealed the most problematic aspects of the employee incentive system, and suggested a systematic approach to improve the process of forming an economic incentive mechanism for enterprise personnel.

Results. The efficiency of industrial enterprises personnel use was analyzed on the basis of comparing the level of labour productivity and the average monthly salary of the personnel, the indicators of productivity of labour and payment of management and industrial-production personnel were calculated. The study of the dynamics of the basic and additional pay growth rates, incentives and compensation in the payroll of the management staff of enterprises showed that accrued bonuses in the payroll fund have a negative tendency. The interdependence between business performance and personnel incentives has been identified. This analysis has revealed the negative impact of certain factors on labour productivity, the main ones being the imperfection of the current labour legislation, the lack of proper control over its observance, the spread of opacity in labour relations and the reduction of social protection of workers.

Key words: personnel, personnel incentives, diagnostics, personnel use evaluation, labour productivity, payroll, labour incentive issues.

doi: 10.31721/2306-5451-2020-1-50-68-73

(c) Kutova N.G., Shakhno A.Y., Demianenko K.O., 2020 
Problem Setting. In the period of permanent changes in economic conditions, special attention is paid to the use of human factors, to the improving of the quality and creative impact of intellectual, human resources, to the improving of the training and use of enterprise staff. The investing to the human resources and enhancing the efficiency of their use are becoming a long-term factor for competitiveness and survival of enterprises. The problem of research is relevant because the decisive factor in the effectiveness of the national economy of any country is the productive forces, the main component of which are people, their skill, education, training as well as motivation. The efficiency of the economic mechanism, the image of the enterprise, its financial stability and success depend on the enterprise providing with qualified personnel, their rational use.

Analysis of Research and Publications. The research of the personnel use efficiency is reflected in the works of both domestic and foreign scientists. A decisive influence on the efficiency of work and the efficiency of the enterprise as a whole has a level of understanding by managers of the importance of enterprise personnel in its development. In modern conditions of management, it is necessary to analyze in more details the use of personnel, their stimulation and motivation to active labour activity, which are able to stabilize the state of activity of enterprises. Competition in the global markets is intensifying and the requirements for the quality of manufactured products are increasing, which is why the enterprises supply personnel is of particular importance [1].

Research Objective and Tasks. The research objective is conducting of personnel incentives diagnostics, by which it is necessary to establish the influence of certain factors on the performance of enterprises personnel and to develop proposals for the creation of a system of evaluating its incentives on the basis of a conceptual model.

Material presentation. The assessment of the rational use of staff should be based on the following [2]:identifying the causes of incomplete or ineffective use of employees working hours (the total amount of direct and hidden losses of working time); deviations of the actual total working time fund from the potential value of the nominal working time, justification of the time losses reasons grouping due to its irrational use; assessing of working time savings reserves and developing the measures to optimize staff performance.

The analysis of personnel support of the enterprises activity should be carried out according to the principles and goals of the personnel policy of the enterprise [3]. The research monitored the personnel incentives, the performance of the enterprise and the assessment of the impact of external and internal factors on the performance.

The analysis of the enterprises' activity was carried out taking into account various factors. In addition to determining absolute and relative dynamics over time, productivity and average pay rates per employee were used to measure the enterprise performance, taking into account both pay and material incentive costs.

The analysis of the average monthly pay for the years 2013-2018 at the enterprises gives grounds to claim that its highest level was at PJSC «Krivoj Rog's Iron-Ore Combine» or PJSC «KZRK» (in 2018 compared to 2013, it increased by 103.92\%), for PJSC «Kryvyi Rih Mining Equipment Plant» or PJSC «KZGO» - 3.34 times smaller than at PJSC «Krivoj Rog's Iron-Ore Combine»(Fig. 1).

Wage is no less important indicator and is defined as the sum of labour costs, which is included to the sum of costs for production (sale) of a production unit (Fig. 2). According to the analysis of wage, we can conclude that salary at enterprises provide not only a stimulating function, but also a reproductive function. The lowest level is at PJSC "MRZ", but there is some positive dynamics at this enterprise - from 0.07 UAH in 2013, to 0.09 UAH in 2018, and at PJSC «KZGO» - from 0.12 UAH in 2016 to 0.14 in 2018 .

Estimation of the average monthly salary and labour productivity of personnel is an important stage in the analysis of the efficiency of enterprises personnel use, therefore, on the basis of these enterprises, the indicators of labour productivity and salary of management and industrial production personnel were calculated. Thus, the labour productivity increased during the analyzed period due to an increase in manufactured goods at the researched enterprises. However, in 2017, compared to 2013, at PJSC «KZGO», the following indicator decreased: labour productivity of management and industrial production personnel.

Also, the efficiency of the personnel of enterprises is characterized by the growth rate of labour productivity and the average monthly salary. It is known that there are prerequisites for the level of 
salary raising with the growth of labour productivity, and the growth of labour productivity should outstrip the growth of salary [4].

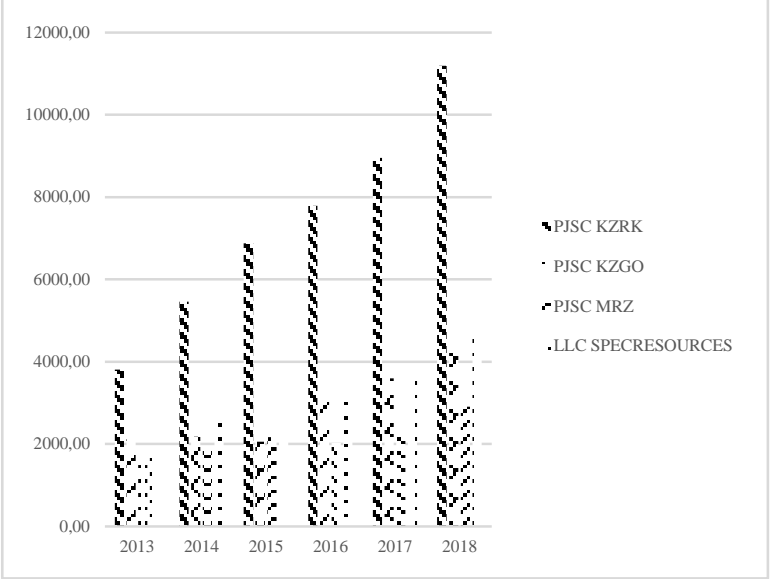

Fig. 1. Dynamics of the average monthly salary of one employee at enterprise

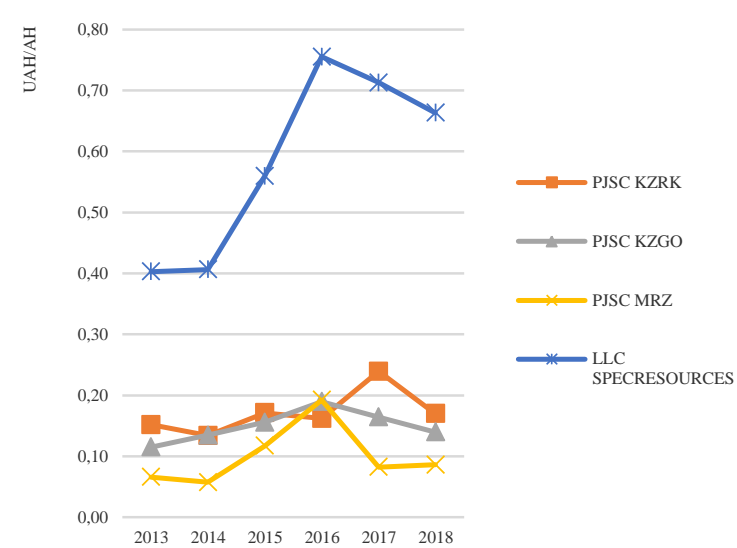

Fig. 2. Dynamics of enterprises production wage

Source: Formed by the author on the basis of Form No. 1 - "Labour Report"

Fig. 3 presents the estimated growth rates of labour productivity and total salary of personnel at enterprises. Therefore, according to Fig. 3 there is a direct link between labour productivity and salary, depending on how the average annual productivity of the employee increases, and the total salary of all the personnel of enterprises. The exception is the enterprise of PJSC «KZGO». Therefore, labour productivity during 2013-2018 increased due to an increase in the volume of manufactured products at the enterprise of PJSC «KZRK».

When analyzing the efficiency of personnel use the working time losses are studied, and the results of the calculations indicate that the largest losses of working time occurred at the enterprise of PJSC «KZGO» - at the rates in 2017, compared to 2013, (increased by $124.6 \%$ ) due to forced vacations caused by the downturn and the financial crisis. PJSC «KZRK» reduced its working time loss by $31.3 \%$ in the corresponding period due to organizational measures for the increase of discipline level.

The age of employees has a significant impact on the efficiency of working time and productivity of the personnel of enterprises. Thus, at all enterprises the largest share belongs to employees aged 35-49 - a zone of sustainable working capacity, which characterizes stable productivity. The rate of change in the age structure of employees at enterprises in 2018-2013 is presented in Fig. 4.

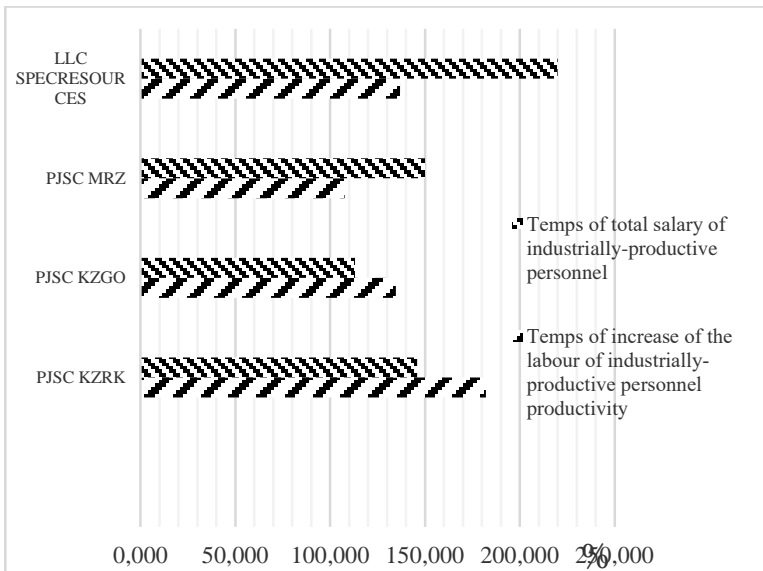

Fig. 3. Growth rates of labour productivity and tota salary of personnel at enterprises in 2018/2013,\% Source: Formed by the author on the basis of Form No. 1 - "Labour Report"

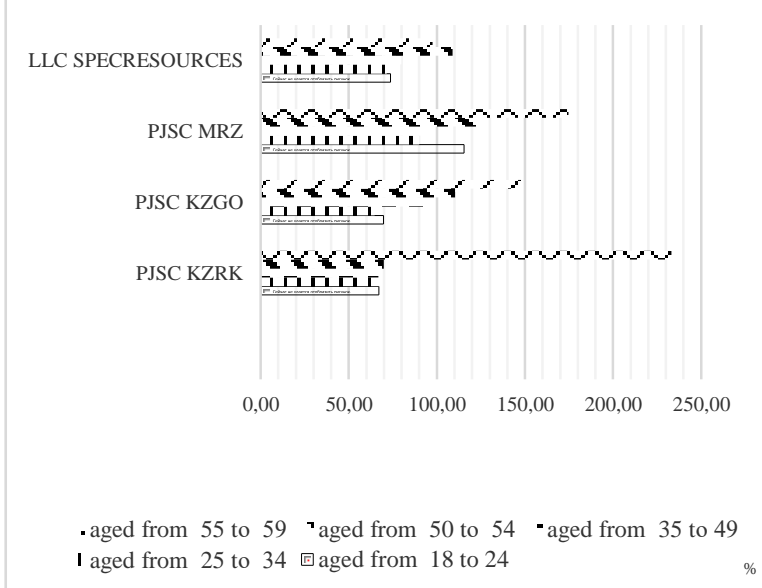

Fig. 4. Rates of change in the age structure of employees at enterprises 2018/2013,\%

Source: author's calculations

For PJSC «KZRK» in 2018 compared to 2013 "aged from 50 to 54" the growth rate of employees is almost 2.46 times, while for PJSC «KZGO» "aged from 55 to 59 " is almost 1,56 times. Whereas 
the industrial-production personnel of the age group 25 to 34 are decreasing rapidly in each enterprise: the growth rate of 2018/2013 for PJSC «KZRK» is 70.314\%, «KZGO»-67.776\%, which indicates ineffective personnel policy that does not provide an influx of young professionals.

Thus, the analysis of employees' age structure shows that, unfortunately, existing personnel incentive measures do not assist fixing of perspective young people in the company.

It should be noted that the efficiency of personnel use depends not only on the correspondence between the professions and the nature of the work performed, but also the appropriate qualifications, so it is advisable to analyse the structure of employees by educational level and work experience, as the necessary production skills and experience are acquired with increasing work experience [5 ]. We will analyse the structure of employees by the level of education at «KZRK». Groups by level of education were formed in accordance with the latest version of the Law of Ukraine "On Education" (Fig. 5).

PJSC «KZRK» has a positive tendency of increasing the number of employees with the master's degree - in 2018 compared to 2013 the share of this category of employees increased $118.77 \%$, accordingly there was a decrease of employees with secondary education.

The indicator of personnel turnover is important among the qualitative characteristics studied in the analysis of the personnel of enterprises,. Every business should keep this figure to a minimum as it helps to increase productivity. Also, the stability of an enterprise's activity is influenced by the average length of service of an employee - his / her life cycle stage in an individual enterprise (Fig. 6). In 2017, compared to 2013, the share of PJSC «KZRK» increased by $113,367 \%$ in the category of employees " $8<$ experience $<15$ years", in the second place - by $107,968 \%$. This indicates the effectiveness of incentive measures.

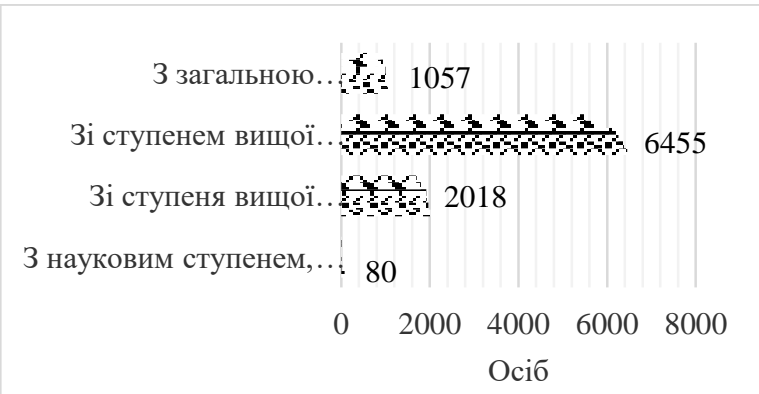

. 2018 \2017 ニ2016 2015 :2014 2013

Fig. 5. Dynamics of changes in the structure of employees by educational level at PJSC «Kryvyi Rih Iron and Steel Works»"

Source: author's calculations

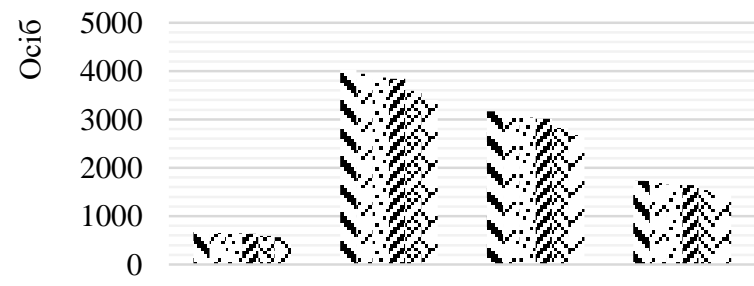

стаж $>3$ років, осіб $8<$ стаж $<15$ років, осіб

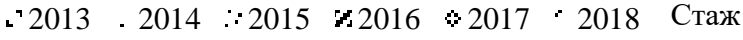

Fig. 6. Dynamics of average length of service in the enterprise on the example of PJSC «Kryvyi Rih Iron and Steel Works»

Source: author's calculations

Analysis of the structure and dynamics of changes in the salary of management and industrialproduction personnel of enterprises shows that the structure of the share of basic salary at the researched enterprises ranges from $60.49 \%$ to $75.9 \%$. Thus, the lowest value of this indicator is at PJSC «KZGO» $(60.49 \%)$, and the highest - at PJSC «KZRK» (75.9\%). The share of additional payment for the 2013-2018 period ranges from $20.24 \%$ to $38.25 \%$. Its highest level in the payroll fund is observed at PJSC «KZGO» - 38,25\%. Bonuses in the supplementary payment fund range from $3.73 \%$ (PJSC «KZGO») to $25.01 \%$ (PJSC «KZGO»), supplements to $8.53 \%$ (PJSC "KZRK"). The share of bonuses in the payroll of enterprises ranges from $6.83 \%$ (PJSC «KZGO») to $11.59 \%$ (PJSC "KZRK"), other payments - from $0.41 \%$ (PJSC “《KZRK»). With the help of bonuses, allowances and other payments, the company can motivate the staff to perform highly productive. The main thing is to justify the factors and define the motivation criteria, as well as to establish the relationship between the indicators that reflect the performance and motivation. Dynamics of changes in the growth rate of the share of bonuses, allowances and surcharges in the total pay bill of the personnel of enterprises shows that the highest growth rates at PJSC «KZGO» in 2018 of the share of bonuses by - 1,61\%, surcharges $-25,58 \%$, allowances $-51,69 \%$.

The impact of material incentives can be estimated by means of regression analysis, determining the relationship between output and staff incentives [6], in particular the components of the additional pay bill (bonuses (X1), surcharges (X2) and allowances (X3) on the output (Y). Calculations made 
with the help of MS Excel, obtained models of influence on the volume of manufactured products for all five enterprises are presented in Table 1.

Therefore, all constructed regression models are significant because the coefficient of determination is in the range from 0.638 to 0.815 . According to the results of the research, it can be concluded that the existing system of material incentives for personnel at the researched enterprises is not effective. Thus, the impact of the factor $x_{1}$ "Bonus» is positive only for PJSC "MRZ": an increase in the amount of personnel bonuses by one hryvnia will increase the volume of manufactured products up to 246.22. The influence of the factor "Surcharges" has a positive value of PJSC «KZGO» and LLC "SPECRESOURCES": respectively, the value of the regression coefficient $b_{2}$ states 146,029 and 6,591 . The impact of the $x_{3}$ factor is positive only for PJSC «KZRK»-the regression coefficient $b_{3}$ is equal to 75.26 .

Table 1

Regression models of the impact of material incentives on the volume of manufactured products

\begin{tabular}{l|c|c|c|c}
\hline \multicolumn{1}{c|}{ Enterprise name } & Multiple regression equation & $\begin{array}{c}\text { Multiple } \\
\text { correlation } \\
\text { coefficient }\end{array}$ & $\begin{array}{c}\text { Multiple } \\
\text { coefficient of } \\
\text { determination }\end{array}$ & $\begin{array}{c}\text { Normalized } \\
\text { correlation } \\
\text { coefficient }\end{array}$ \\
\hline PJSC «KZRK» & $\mathrm{Y}=-1181123-11,0 \mathrm{X}_{1}-37,54 \mathrm{X}_{2}+75,26 \mathrm{X}_{3}$ & 0,871 & 0,759 & 0,397 \\
\hline PJSC KZGO & $\mathrm{Y}=556578,2-82,326 \mathrm{X}_{1}+146,029 \mathrm{X}_{2}-5,68 \mathrm{X}_{3}$ & 0,903 & 0,815 & 0,538 \\
\hline PJSC «MRZ» & $\mathrm{Y}=12034,72+246,223 \mathrm{X}_{1}-330,13 \mathrm{X}_{2}-24,071 \mathrm{X}_{3}$ & 0,799 & 0,638 & 0,095 \\
\hline LLC “SPECRESOURCES" & $\mathrm{Y}=5778,116-1,609 \mathrm{X}_{1}+6,591 \mathrm{X}_{2}-2,9161 \mathrm{X}_{3}$ & 0,891 & 0,796 & 0,445 \\
\hline
\end{tabular}

Source: author's calculations

The main problems of personnel incentives are formed on the basis of researches of activity of managerial and industrial-production personnel [7-9]: absence of an effective mechanism of stimulation of personnel, especially young people; inconsistency of the current mechanism of personnel incentives to European practices; ineffective application of scientific approaches to human resources management, especially of young specialists and skilled personnel; poorly developed social infrastructure; sub-optimal structure of the social package (problems with housing, lack of non-state pension insurance); dissatisfaction with the primary social needs of employees (transport, clothing, etc.); inconsistency of the safety system, unsatisfactory level of responsibility of the personnel for performance of work; the level of payment that does not meet the expectations of employees and the level of inflation, low investment in personnel development; negative dynamics of growth of satisfaction of needs of personnel, consumers; deterioration of business reputation of enterprise (decrease in market share, loss of trust of business partners); the imperfection of the incentive system. [10]

Conclusions and Further Research. As a result of the study of industrial enterprises, it was found that the formation of the mechanism of personnel incentives is adversely affected by a number of factors as following: the imperfection of the current labor legislation, the lack of proper control over its observance of the transparency of labor relations, and the reduction of social protection of employees. While improving the economic mechanism of staff incentives, the main prerequisite is the development of a system for evaluating its incentives based on a conceptual model. The results of the research allowed us to identify the most problematic aspects of the personnel incentive system, to offer a systematic approach to improve the processes of forming an economic mechanism for personnel incentives of enterprises, taking into account the integral indicator of the evaluation of motivational processes.

\section{References}

1. Kutova N. Analysis of the influence of labour and investment factors on production volumes: international scientificpractice. Conf. Sustainable Development of Mining and Metallurgical Industry, May 25-28, 2011, Ukraine,. Kryvyi Rih: Kryvyi Rih. Univ, 2011. P. 44-45.

2. Kutova N. Methodological bases and advantages of material incentives for personnel: materials of international. Research Practice Conf. "Actual problems of economic development in the context of global challenges", September 19-23, 2013, Odessa, Ukraine: Odesa Nat. econom. Universities [and others] - Odessa: Atlant, 2013. - P. 58-61.

3. Kutova N. Comparative Analysis of Enterprise Personnel Incentive Systems: Materials I Intern. Research Practice internet conf. Strategic-Innovative Development of Economic System Entities in the Globalization Conditions, 16-18 November 2016, Kremenchuk, Ukraine: Kremenchuk National University after M. Ostrogradsky [and others] - Kremenchuk, 2016. 298 p. P. 31-33.

4. Kutova N. Research of factors of influence on procedures of stimulation of work at the enterprises: materials «Current status and problems of development of statistics, accounting and audit in the conditions of globalization and energy 
saving»: Proceedings of the 5th International scientific-practical conference (Dnipro, April 4-5, 2017). In 2 volumes. Dnipro: DNU O. Potter, 2017. Tom. 1, P. 127-130.

5. Business Description [Electronic resource]. - URL: https://www.stockworld.com.ua/en/analytics/emitent /template/49004/156

6. Yeliseyeva O. Statistical analysis and modelling of socio-economic processes. Dnepropetrovsk: "Science and education" 2012. $216 \mathrm{p}$.

7. Eckerson U. Indicator panels as a management tool: key performance indicators, activity monitoring, performance evaluation. M.: Alpina Business Bucks, 2007. 400 p.

8. O. Akimova, A.. Baldak, P. Vavulin, S.V. Voitko, OA Havrysh [and others] Sustainable development analysis global and regional contexts: Monograph. Int. the Science Council (ICSU), etc .; of scientist M. Zgurovsky. - K.: NTUU "KPI", 2014. Part 2. Ukraine in sustainable development indicators (2013). 172 p.

9. Grishnova O. Personnel assessment: current approaches to ensuring efficiency. Human Resource Management: Problems, Theories and Practices. 2010. № 7. P. 42-50.

10. Oksana Jelisejevá, Natalie Kutová Teoretické a metodologické aspekty řízení zaměstnanci průmyslových závodů. Praha: OKTAN PRINT s.r.o., 2019. 212 p.

The editorial board received a manuscript on 24.03.2020

\section{УДК 622.684}

В.І. ПАХОМОВ, канд. техн. наук, доц., І.В. ГІРІН, ст. викладач,

В.С. ГІРІН, д-р техн. наук. проф.,

Криворізький національний університет

\section{ДОСЛІДЖЕННЯ ТА РОЗРОБКА ЗАХОДІВ, СПРЯМОВАНИХ НА ЗНИЖЕННЯ ТОКСИЧНОСТІ ВИКИДІВ ПРОМИСЛОВОГО АВТОТРАНСПОРТУ}

Мета. Основною метою роботи є кількісна оцінка забруднення атмосфери викидами автотранспорту підприємств в умовах Кривбасу і розробка аналітичної методики комплексного підвищення екологічної безпеки шляхом зниження рівня шкідливих викидів від промислової автотехніки в навколишнє середовище.

Методи дослідження. В роботі використовувалися як теоретичні (математичне моделювання, використання теорії планування експерименту), так і експериментальні методи дослідження. Також застосовується ряд приватних методів: аксіоматичний і гіпотетичний методи, аналіз та синтез, метод інтерпретації. Вихідні дані були отримані шляхом обстеження міських транспортних магістралей і аналізу автотранспортних потоків гірничодобувних підприємств м.Кривого Рогу.

Наукова новизна. В роботі отримані наступні наукові результати:

розроблено метод прогнозу забруднення повітря автотранспортом для окремих ділянок автодоріг;

розроблені статистичні схеми прогнозу шкідливих викидів автотранспорту за матеріалами спостережень у Кривбасі;

розроблені методичні підходи прогнозування забруднення повітря автотранспортом на перспективу з урахуванням запланованих заходів щодо зниження промислового транспортного навантаження на атмосферне повітря;

розроблена методика обстеження складу і інтенсивності викидів потоку промислового автотранспорту.

Практична значимість роботи. Розроблені модель, методика і програма розрахунку показників режиму руху i питомої витрати палива на 1т км виконаної транспортної роботи дозволяють для конкретних умов експлуатації обгрунтовано визначити оптимальний режим руху транспортних засобів, який поряд 3 максимальною умовною питомою продуктивністю забезпечуватимуть зниження концентрації шкідливих викидів рухомого складу під час експлуатації.

Результати. Розроблено методику щодо ефективної експлуатації промислового автотранспорту. яка дозволяє істотно підвищити екологічний ККД рухомого складу. Запропоновано рекомендації щодо зниження автотранспортного забруднення повітряного середовища міста, які грунтуються на організаційних, технологічних і конструктивних рішеннях. На підставі проведених розрахунків полів концентрацій шкідливих викидів розроблений комплекс заходів щодо зниження рівня забруднення від промислового автотранспорту, який може бути використаний в виробничих програмах,

Ключові слова: промисловий автотранспорт, експлуатаційні властивості, електромагнітний паливний фільтр.

doi: 10.31721/2306-5451-2020-1-50-73-78

Проблема та їі зв'язок з науковими і практичними завданнями. Однією з гострих екологічних проблем теперішнього часу є забруднення атмосферного повітря. У великих містах до числа основних джерел забруднення атмосферного повітря належить автотранспорт, парк якого в теперішній час налічує понад мільярд одиниць в світі. Гази, що відходять 3 двигунів, містять складну суміш з більш двохсот компонентів, серед яких чимало канцерогенів. Автотранспорт є,

(C) Пахомов B.I., Гірін I.В., Гірін В.С., 2020 